\title{
An Informal Occasion with Robert Hass*
}

Q: Why a prose poem, and what is a prose poem?

RH: I haven't arrived for myself at any very satisfactory formulation of what a prose poem is. Certainly it has something to do with condensation. If it's narrative in form and gets to a certain length, it's probably a story; if it's very short and in a book by a fiction writer, it's a sudden fiction; if it's in a book by a poet, it's a prose poem; and if it gets to a certain length, it's an essay, or a sketch, or something like that. So I suppose condensation has something to do with it.

I don't know how to define it in terms of genre, and when I was working, I guess I just stopped trying to think about that. What I did think about was what the conventions of the prose poem were. At the time that I was starting to write them, the prose poem, as it had been revived in America, was used almost entirely for a kind of wacky surrealist work, and I think that nervousness about using prose was that then you had to put a lot of what people thought was poetic-that is to say, wildness and imagination and free association -into it to make sure that it was poetry, because if it got too near the conventions and sentence sounds of expository prose or narrative prose or something like that, then it really wasn't poetry. So almost as soon as I started working, I got interested in those boundaries: what the prose poem wasn't supposed to sound like.

I think I came on it in the first place from writing prose. When I was writing essays, I found that there would be a passage where I wanted to give an example, or tell a short anecdote to make a point, and that I would find myself laboring over the making of that paragraph with the kind of pleasure I get from working on a poem. So that was in my mind with "Museum"- the prose poem about the young man and woman handing their baby back and forth in the restaurant. It was very hard to . . I had seen it and I was very moved by it, but I couldn't find a rhythm for it. Each time I got into it there was some prosodic problem with the business of people handing each other the baby, back and forth. If I wrote it sort of

* Unfortunately, not all of the questions that arose during this session held in November 1989 were preserved on tape, and so we leave some of them to your imagination. 
contrapuntally, it had an elegance that I didn't want. And if I enjambed the line so that it wasn't one line playing off another, it had a jaggedness I didn't want. I could not find a way to do it, and at one point, in frustration, I turned to the side and wrote out as clearly as I could-you must have done this -in pencil, exactly what I was trying to get at. And then I realized . . . why, then, convert it into something else? So then I went to work on that, and thought that I had written a prose poem. And also for me it was a little narrative. It almost seemed like photography to me, and it gave me a feeling that I wanted to experiment with the form, and so I started doing it.

I wrote a whole lot of them, and I got interested in textures, the way that you would with a given palette. Every time I picked up a piece of prose, the sound of it was like a color. I mean, I picked up a John Le Carré novel, and I suddenly noticed that all of his sentences are terrifically suspended, because suspense is what he's thinking about. So a sentence would go, "In Prague, on a gray afternoon, an old woman - she was not as old as she seemed, the streets were not as old as they seemed, and they seemed ancient - was making her way, however fitfully, the rains are always difficult . . ." That kind of almost Jamesian sentence has to do, in his case, with these labyrinth- and maze-like mysteries that are always in his books. Anyway, I loved that tonality of sentence, so I wanted to sit down and do something in that tonality of sentence. It would be like the color on a palette. So I began "Churchyard" with the sentence: "Somerset Maugham said a professional was someone who could do his best work when he didn't particularly feel like it." I had read that sentence in the paper the day before, and it was in my head, and I was wondering if it were true (wouldn't it be great if that were true!), and thinking I'll never be a real writer because I can't do that. And so I sat down to the sentence, and as soon as I wrote it -I don't know if the poem is any good-I felt excited because I knew it was exactly what the prose poem wasn't supposed to be. It was too much like the sound of expository prose.

So for a while, it seemed to me that this opened up everything. I'd sit at a dinner party and people would start telling their anecdotes, and the shop door would open, and I would sit there with a smile, listening, waiting for something I could use. And all the stories that $I$ had told, that I wanted to write down before I died, or they would be gone-I thought I could do 
it with this form. Then I found out that it didn't work, that it was very complicated, that some of them wouldn't accommodate themselves to this form: they took too much telling, or they weren't my story.

Later, something else occurred to me: I was working in these forms because they had a certain outwardness that verse didn't have. I think I was at a time -I mean I know - when things were going on in my life that I didn't want to look at, didn't want to feel. And I wanted to keep writing, so I unconsciously started writing prose to avoid the stricter demands of incantation. When I was doing it, it seemed to be exploratory; in retrospect, it seems a sort of long escape.

RH: William Stafford's conversational naturalness is not an ideal for me. I like a certain kind of appearance of naturalness in a poem, and in writing, I love plainness. It seems to me, a lot of the great lines of poems that I love are very simple. I love Wordsworth's line, "All things that love the sun are out of doors." [Frost's] "Nature's first green is gold." [Stevens's] "Among twenty snowy mountains, / The only moving thing / Was the eye of the blackbird." Much of what's in my head, what appeals to me, is not [Crane's] "How many dawns, chill from his rippling rest / the seagull's wings shall dip and pivot him." I love that language too, but I'm always most amazed by great plainness in language.

I became aware of a bunch of possibilities. One had to do with a poem I absolutely love by Robert Duncan. It's the second poem in his book The Opening of the Field, and it's called "The Dance." It's written in his high, ecstatic style, and it addresses some of the characters in his Victorian fairy tale mythology: the lady under the hill, and the voice that tells him to dance. Then suddenly, toward the end of the poem, this prose voice breaks in, and says, "That was the summer I had the job sweeping on Saturday mornings," and it describes just briefly in prose this memory of having a job sweeping the dance floor in Larkspur. [Turns to Linda Gregg] Do you remember the name of the place? They used to have the dances? My older brother went, then it closed, just at the time I was old enough to get to go. It's one of those things I'm never going to get to do in my life. So Duncan, in the forties, had the job of sweeping this place on Saturday mornings, and he breaks in with the story of it, and a memory of being taught to dance by the family's German maid, and then he comes out of it 
again, and the voice says to him-it's partly the German maid's voice and it's back in the language of verse - "You have entered the dance-dancer." The juxtaposition of the prose of the memory with the higher mythic voice is incredibly beautiful to me. I would like to get that.

There's another place in a poem by George Oppen called "Route" which is one of his two or three greatest poems, I think. He's musing along in that sculpted, difficult, austere, beautiful verse, and suddenly he breaks off and there's a prose passage: a young Alsatian in World War II was conscripted by the Nazis to fight. If he did fight, some terrible consequence followed for his family, besides the fact that he had to do a dishonorable thing; and if he didn't, and went into hiding, they were arresting and deporting the families of the deserters who failed to report. So he had a buckdancer's choice. What he did was kiss his wife goodbye, kiss his kids goodbye, and get on a bicycle and ride downhill very fast into a tree and kill himself. That way he guessed his wife and children would not suffer German reprisals. It was a solution to their problem. And Oppen just tells the story in the plainest way, in the plainest language, and then moves back into the musing, austere music of verse again.

I didn't know how to get to either of those things, but the whole time I was working on the prose poem I knew that somehow I never particularly loved the idea of the prose poem. But it was interesting to me to think about a larger form that might mix verse and prose.

Two formal models of mixing verse and prose have occurred to me since. One is Shakespeare's comedies, which are just amazing - a totally delicious mixture of verse and prose. I don't know who you would imagine putting together-I was going to say Milan Kundera, but he's not earthy enough. I don't know whose prose ... Faulkner's storytelling side, mixed with James Merrill, all into one large form, or something like that. So I began to imagine that, and then of course Japanese haiku journals are another example of that kind of thing. At that time, I had already begun to work on Milosz's poems, but I hadn't yet seen him working in some of these longer forms where he had experimented with verse and prose.

There are lots of convergences going on right now with poetry and prose, and lots of different kinds of writing working the boundaries between the two, but it seems to me that, as a form to be figured out and exploited, we haven't even begun. The next great epic work, I would 
guess, is likely to be a mixture of the two. We haven't started to tap the possibilities. We were talking about Carver and Barthelme both dying. Barthelme's stories always seemed to me to have been written essentially by a poet, as if they're an extension of the early work of Wallace Stevens in their formal imagination, and Ray, of course, worked in both media and at the end began to blend them. There's that on the one hand. There are the strategies of Kundera's prose on the other hand which introduce other kinds of prose-expository, critical-into the narrative. And then there are intensities in verse that just aren't available to prose. This is not where I am working right now, but it's certainly there for me, and it's there for you, God knows.

I think this is a very interesting time to be working, because lots of formal options are open. There's a kind of rawness and questioning in the political and social world, as well as some peculiar urgency because of the century coming to an end. And there's no proposition of a form for a long ambitious poem. I mean, I don't think anybody wants to try the cantos again-another modernist epic doesn't seem to me just the ticket. That's how this prose thing - how the revival of realism in the other arts-plays into this in fiction and in painting. I mean, for example, a kind of expressionist representative painting, melody coming back into music.

Q: Are the "Spring Drawing" poems at the beginning of Human Wishes prose poems?

$\mathrm{RH}$ : I thought of those poems absolutely as verse when I was working on them. They began actually with fooling around and sketching. I had been reading Michael Palmer's Notes for Echo Lake - and particularly that poem I love - and in the way that you might sit down and try to imitate Roethke or somehing like that, I sat down and tried to see what would happen if I worked in a mode something like that. As I was working on one of them, I was playing the line out to the end, and the first one that I wrote ended up being twelve lines long. The fun of it was that almost immediately I realized that it was going to have a formal shape, and that the form would probably be a certain number of lines, but also that if you used these long looping lines and then stopped, it was like long oar strokes, and then you stood for a while, and then another long oar stroke, and so on. It created that kind of formal measure in which you could fool around a lot. So you 
could have long lines and short ones. So then I just made a rule: that it was a new kind of sonnet I had invented, and it was twelve lines long. But the other rule was that each line could be any length, up to Paradise Regained, that you could just go on forever. But the poem would have this series of strokes, so the rhythm would be something like:

Now the rain is falling, freshly, in the intervals between sunlight, a Pacific squall started no one knows where, and drawn east as the drifts of warm air make a channel;

it moves its own way, like water or the mind,

"Spring Rain"

-a relatively short line to vary it, then-

and spills this rain passing over. The Sierras will catch it as last snow flurries before summer, observed only by the wakened marmots at ten thousand feet,

and we will come across it again. ...

\section{"Spring Rain"}

You see? Then it was like a territory to play in, and I could alter the rhythms:

And then in mid-May the first morning of steady heat, the morning, Leif says, when you wake up, put on shorts, and that's it for the day,

when you pour coffee and walk outside, blinking in the sun.

Strawberries have appeared in the markets, and peaches will soon; squid is so cheap in the fishstores you begin to consult Japanese and Italian cookbooks ...

"Late Spring" 
For me it was absolutely verse, utterly verse, in the sense that it had everything to do with rhythm, and when I sent them to magazines, right away they said, "These are in your new 'prose poems period," " and I thought, "Oh, shit."

Q: I tried to discover a formal rule for where your lines are divided. They seemed to me to do what Williams does sometimes, that there is a gesture of thought. In Williams they tend to be very small, two or four words, but there's one gesture of thought, and as soon as the gesture of thought ends, even if it's very short, then the next line begins. So they seem to me to have that rhythm.

RH: I wasn't aware of it before, but afterwards I thought, that's exactly right, it's like Williams's variable foot. That's what I had in mind, though I didn't know it. The same analogy occurred to me. Again, working, it was my experience that almost everything I've done in the last few years, I would turn to another phase of Milosz's life and find that he had already done it. Then it seemed to me that that dithyrambic verse, longish rhythmic verse, strophes, or whatever you want to call it, was completely typical of European poetry all through the twentieth century. St. John Perse is the great example, but there are a lot of others. Let's see if there's an example in [Milosz]. It's a form he uses ... not quite the way I did. Of course my Polish is nonexistent, so I can't tell. I mean I could begin to pick it out with a dictionary, but I can't tell what kinds of formal stringencies are in the sound of his poetry. The Polish language tends to sprawl anyway because it has a Latinate syntax. It would seem that all you could do is make a comedy of the sprawl, but he does something else here: this is a three-line poem, each line very long. It's not the same thing, but it's near to it.

I looked out the window at dawn and saw a young apple tree translucent in brightness,

And when I looked out at dawn once again, an apple tree laden with fruit stood there.

Many years had probably gone by but I remember nothing of what happened in my sleep.

$$
\text { "Window" }
$$


That's a kind of long epigram, but its rhythmic idea is to play with a very long line. And it's verse, you know? As you say, take each one in as one measured unit of thought or perception.

Q: I wonder what your thoughts are about being a poet in America in the '90s, and particularly in terms of politics.

RH: Well, it's a dilemma to know how to be political now and also how to think about politics, but it's a dilemma whatever you are. It would be a dilemma if you were an engineer - what am I doing, pissing my life away being a traffic engineer? When I was in graduate school, I was very involved in politics. In Palo Alto, a group of us started a newspaper, a community self-help organization, and a free university, and there was a political organization that went with all of this. When I finished all my graduate work, I had to make a decision, whether to stay there and figure out somehow to make a living while continuing this work, or go be a professor and get on with my life as a writer. I thought I could be a writer doing either thing, but I knew that I couldn't give myself wholly to both things. And I hated meetings. You know, so much of politics is going to meetings; you have to be patient, listening to people who are completely full of bullshit. Everybody has to get their turn saying their thing, you know. Oscar Wilde said, "Socialism takes too many evenings!" A guy gets up and has to give a long talk on why Ho Chi Minh was a deviationist because he had all the Trotskyists eliminated from the labor movement in Hanoi in 1945 before taking over, just as a preface to some remark about whether we should go from door to door leafletting. I absolutely couldn't stand it; I'm not a methodical person and I wasn't good at it. A person who was a big influence on me at that time was Paul Goodman, who, when I talked to him about this, said, "Do what you love, and it will take you into a job and a way of life - change that so it's a human place." So hating politics, I ended up teaching at this little college where I was captive to meetings because my friends' jobs were on the line. Any form of life you get into is political in that way.

The job itself, my own writing, and the kind of emotional issues I deal with in the writing all took me away from politics outside my immediate community. Field Guide is in some ways a political book; Praise is, it seems to me, a mostly apolitical book, because I was so concerned with my erotic 
and epistemological agonies. The social world returns a bit in Human Wishes, and I think it will be there in the things I'm working on now. I think that if you're somebody who thinks about that stuff, it enters your writing. And for some writers - if you're South African or something like that -it's an inescapable subject. The problem for American writers, particularly for white male American writers, is that it is an escapable subject. There are subjects that are not escapable, but for me, it is escapable.

It's one of the reasons why the writing on the peripheries seems so interesting now. John Coetzee and V. S. Naipaul, people who testify out of explicitly political situations, seem terrifically attractive to me and at the same time I'm suspicious of my attraction. I think we're all haunted by the martyrdom of Mandelstam out of a kind of bad conscience. Seamus Heaney's book The Government of the Tongue is a disturbing book to me, because as much as I admire him, and admire his work, and find his critical prose delicious, I'm bothered by something I recognize in myself: thewhat's the word-longing in his attitude toward Eastern European poetry - where poetry really mattered. It made me uneasy about that book. I'm not quite sure I understand the Irish context, the problem of what poetry can do in the face of intransigent tribal fury, but I know that there's something a little bad-conscience and voyeuristic about an American reading of those materials.

Poetry is a phenomenon of the urban middle class: a phenomenon of the urban middle class in Korea, a phenomenon of the urban middle class in New Zealand. It's an urban middle class that doesn't particularly want to be urban and middle class, and often, if it has roots in the country, it draws strongly on those roots and is the place that articulates them. But really, since Alexandrian Rome and Athens, poets came to the city, poetry was preserved and disseminated through the cities, and consumers of poetry were the citizens of the cities. It's the problem of displacement-by the time people are comfortable enough to be in a situation to study and write poetry, the situation has been displaced. It's amazing how a young Indonesian poet, who you would think would live among the sweat shops and see, is just as blind, just as cut off from those things by class, habit, roads through town, as we are. So displacement becomes the great subject in a certain way. That's why I think V. S. Naipaul, however odious his politics can sometimes be, is a great political writer, because he writes so brilliantly about displacement. 
Anyway, I think about politics a lot; I go through periods when I don't think about it at all, but then at other times I think about it a lot, and I've written about how one thinks about it. I don't think that there's an easy solution to the present retreat. The nineteen-eighties was culturally and politically a sink of a decade, the worst in America in this century, and I think we all feel somewhat defeated by it, by Reagan's popularity, by the unconsciousness and greed.

You all know the story about George Oppen? In 1931, '32, whenever it was, he went to New York and met Williams and Zukofsky. He had a little bit of money, a family inheritance, and started a press, The Objectivist Press. He published some Williams, published some Pound, and was going to be their younger protégé with a little money starting a press along their lines and getting something going. Pound was always enthusiastic about these things, especially having a rich young Jewish guy from San Francisco set up a press where he could print his "funny money" pamphlets. Anyway, Oppen wrote one book of poems while he and his wife Mary were living in Brooklyn. The Depression was devastating in New York City, so he made a conscious decision to organize rent strikes, and to not write poetry. Since he didn't want to be torn between the two, he set poetry aside, and he and Mary joined the Communist Party. He spent four or five years organizing rent strikes in Brooklyn, helping the people with housing, and so on. Then later he worked in factories and served in the Army, and after the war, having fled to Mexico to avoid the McCarthy thing, he suddenly started writing again. It was 1954, I think, and he was reading Jacques Maritain's book Creative Intuition in Art and Poetry, a wonderful book, and he started writing poetry, twenty-five years after he set it aside. What's so wonderful for me about his poetry of the later years is that he's not trying to prove he's a really good person in the poems. He'd absolutely done his work of conscience, and set it aside, so that when he came back, he wrote a kind of Heideggerian poetry. It's also a social poetry of curiosity, a phenomenological poetry, full of tender but suspicious and absolute curiosity about being. It's authentic in part because he doesn't ever have to demonstrate that he's political-he's already done that.

I think political writing is problematic. Neruda wrote a lot of bullshit, because he wrote political poetry, and a lot of it is gesturing and posturing. It made possible "The Heights of Macchu Picchu," which is very great and 
actually a kind of politically confused poem, I think, in the way that Ginsberg's "Howl" is a politically confused poem. But the confusions don't matter in certain ways.

It makes me think of Polish poetry, of the poetry written by writers of my generation in the sixties -it's not readable much now. They all wrote a consciously political poetry that's very clever. I mean they would take the language of the media and the broadcasters and turn it on its ear. They did a reportorial and a documentary poetry, but it was stuck in the outward world in a certain way. And when they became dissatisfied with itBaranczak, Zagajewski, Krynicki, and others - each of them at some point made a decision not to let Polish politics so dominate their imaginations that they didn't write about everything else that was inside them. Then the poetry took off, and in the Eastern European context, it became more political to be antipolitical than to be political. The Hungarian novelist Gyorgy Konrad's very interesting book Antipolitics is another instance of that.

In the United States, in the center of the empire, this same freedom can be problematic. During the sixties, some people were furious at Ashbery and O'Hara; O'Hara in particular seemed maddeningly narcissistic. There was this stuff going on, American tax money was being spent on incinerating a whole culture, and he was writing about what color belt to buy on his lunch hour, and it pissed people off. People say that being antipolitical is ultimately subversive, but there's always Oppen's example hovering over one's head, saying that subversive is a dime a dozen, all artists think they're subversive. Don't flatter yourself. "Howl" seems to me the nearest thing. There are two things besides the invention in the language that make "Howl" a great poem, I think. One is the vision of Moloch. Milosz says American poets are juvenile, mainly because they have a vision of bad guys but they don't have a vision of evil-but Moloch is a vision of evil. The poem names the soullessness and fear in all of us that produces the horror, and really does it in a powerful way. But the other thing that makes it a great poem is that it's ultimately about his mother. When you get to the asterisks at the end of the first section, the final image of the poem is "down to the last piece of mental furniture, a yellow paper rose twisted on a wire hanger in the closet, and even that imaginary . . ." It's his image of Naomi, his fury at his mother's madness that's at the core of that poem. That's the great thing about Ginsberg - it would have been easy for him to 
write a poem in which American society did that to Naomi, but he's not sure what did it to her. So there is this personal lyrical agenda, this elegiac agenda, this ontological agenda of grief and rage that is anchored in the absolutely personal. That's why I'm slightly suspicious of the term "rhythm of the streets," as applied to Ginsberg, because the rhythm that artists are ultimately responsible for is the one that the rhythm of the streets produces in them.

RH: Recently I've been listening to the graduate students give talks, and to some of the lecturers who come through Berkeley. It fascinates me that all of the criticism is written from the point of view of a total superciliousness toward literature. It's really the old French thing: it's a new language, but they pull the same rabbit of bourgeois ideology out of the same hat of literary analysis. Which is okay $-\mathrm{I}$ think disenchantment is an important work of the mind, but it's their position of superiority that puzzles me because it's based on the implicit, usually Marxist, idea that they have a superior vision of social and political economy. But they fail to acknowledge that something has collapsed in Eastern Europe, that began, as Kundera's books say, in Utopian joy. As a result, the position which this criticism is based on has collapsed, and you'd never know it from the viewpoint of the academics, who still get up there in their Italian suits and give these incredibly witty contemptuous lectures on how the poets and the novelists don't understand the bourgeois ideology of what they're writing. It enrages me.

Meanwhile the whole world is being sold the bill of goods that somehow this system has triumphed, a country whose cities have something like twothirds unemployment of non-white males between the ages of eighteen and thirty, and half of the country, especially white, white-collar workers, addicted to crack or cocaine. I mean - leave alone the question of homelessness - this country is in catastrophic condition, and the media's got everybody convinced that we've found the victorious solution-and I mean, if this is the solution ... .

So, all political questions seem to me open and really puzzling. It looks like it's going to turn out that the intellectuals of the 19th and 20th centuries who didn't favor the market system were wrong about it - the same system the jocks and the cheerleaders we went to school with loved, and 
went out to be part of, and get the goods in. We went off to talk about how terrible it was and about what kind of rules we'd set up for a government that was fair to poor people - which meant that we were in favor of imposing moral authority on the economy from above-and it hasn't worked anywhere. So it turns out that all the people I hated in high school might have been more right than I was about this stuff. And every time one of the people like me got into power-Ho Chi Minh or Ortega or someone like that - he turns out to be another moralistic authoritarian. Or something else: Castro may not be a moralistic authoritarian, but at the least, he's a king.

So it's puzzling. I know what I hate, but I know less and less about how to change it. That's why I said in "Rusia en 1931":

Poetry proposes no solutions: it says justice is the well water of the city of Novgorod, black and sweet.

Mandelstam's great political ideal was the Italian city-state, and the most Italian city-state in the Russia of the Middle Ages was Nizhni Novgorod, and it was famous for being a free place because they didn't tax you for the well water. Anybody, citizen or not, had access to the well water at any time. It was his image of a just, small society. And I think that's right; I think the task of art is to over and over again make images of a livable common life. How do you retranslate "Crossing Brooklyn Ferry" into the 20 th century? Alfred Corn tried to do it -it's really a noble experiment, I think, in A Cry in the Midst of the Crowd. I so admire the impulse of it, especially from him who's such an elegant poet. He tried to do it. O'Hara in his way-in Lunch Poems especially - tried to do it. You know, it's not everybody's world, the art scene in midtown Manhattan, but he tried to get some of common life into his work. So that's one task.

Another task is to make images of justice: make ideal images or make outraged images or just do witness. There are all the usual tasks. You'll always feel a bit of a tourist in them, you know, as in Linda Gregg's wonderful poem about visiting the women's shelter. It's part of the job of being a poet, but I think you'll always feel a little bit like a voyeur and a tourist writing those poems. And a little uneasy reading them. But the choice is that or silence, and so you do it. Or Jorie Graham's poem about 
Paris in '68 - when political experience comes your way, you write about it. The trick-I've seen it in Milosz's work especially-is to write very honestly about the actual dilemmas, which means thinking about them clearly, which means not flattering yourself that you know what the solutions are. At some point, somebody's going to see things truthfully, as with "Howl." There are just moments when somebody finds a way to say it, you know, stumbles on it. I've just been reading that biography of Ginsberg, who had sort of an unpromising start. He went to an Ivy League college and got taught by Lionel Trilling and had a lot of his classmates become editors and stuff like that. So he had access to and understood very well the publicity mechanisms of American writing, but he had such a miserable family life and terrible personal dilemmas. And out of some combination of guts and talent, he stumbled into telling the truth in some powerful way, raggedly and imperfectly. And I feel that will happen again. Certainly everybody would like to do it, or at least have their writing be part of the writing that leads to it, and I think of Milosz's example, and in a way of Ginsberg's example, of not writing from knowing the answers.

I don't know if any of you have read Coming to Jakarta yet. Peter Dale Scott is my colleague at Berkeley; he's a Canadian poet in his late fifties and his father's a very distinguished Canadian poet who was one of the founders of the Canadian Socialist Party. And Peter went through traditional Canadian upper-middle-class education-McGill and Cambridge, or whatever - and then he joined the diplomatic corps. He worked in Poland, then in Indonesia, then at the UN, and then he quit and became a high school classics teacher, and somehow he ended up teaching Latin to English medievalists at Berkeley. During the Vietnam years, trying to figure out what started that war, he began doing research on the cocaine traffic and the CIA involvement in Central America and Southeast Asia, and wrote a couple of books about these subjects. He's a very interesting guy; he spends his time in the English department and in Washington think tanks. He's developed into somebody who has a way of putting all of his previous political stuff together, and it's finally erupted into this Poundian poem.

At some point when he was doing research, it dawned on him that Lake Massawippi, where he'd summered as a kid, had these genteel academic 
cabins on the Canadian side - you know, Pendleton shirts and rowboats and minnows and fishing for pike-while on the other side, the whole American ruling class had these incredible, elegant places where they mingled. So as he read with outrage about the founding of the CIA, and the founding of the Council on Foreign Relations, and how all of these people had taken it upon themselves to police the world, it dawned on him that Lily Dulles, whose house they'd always picnicked at on Sundays, was in fact the sister of Allen and John Foster Dulles. So what emerges in the poem is both a reconstruction of his own childhood and a realization that he was spying on the set of social connections that created the CIA and the Council on Foreign Relations.

The Council on Foreign Relations was the group of interested businessmen and intellectuals and bankers from John McCone to David Rockefeller who have dominated American foreign policy - really created it since the Truman administration. The poem is about all of that, and it aims toward trying to figure out what brought about the counter-revolutionary massacre in Indonesia in 1962 that killed an estimated one million people. It started as a purge of radical elements in Indonesia and ended up as the slaughter of the Chinese in Indonesia. It was partly just a racial pogrom, but it also wiped out almost every communist, which is to say almost every schoolteacher and incipient middle-class person in a peasant society. It was a horrible slaughter and the CIA was-unquestionably-implicated. From their point of view it got out of hand, but it's one of the real horrors of the twentieth century, equal in horror to other more infamous events. And what Scott has done is construct this poem that begins with flickering memories of looking into the water, into the reeds, and getting a creepy feeling at Massawippi. Then it moves to a series of images: little bits of Indonesian shadow dance with violence and destruction emerging in it, stuff about the drug traffic as it was formed in the 1950s, stuff about the parties at which John Foster Dulles and Allen Dulles connected with the bankers, and so on. ... It's a political poem that actually tries to be informed by a knowledge of how the horrible events of the twentieth century have come about, and it's an amazingly interesting poem, a very ambitious poem. Which is to say you should read it.

I guess a lot of the questions in poetry can only be answered by poetry. That is, they can only be answered by dramatizing and intensifying the 
contradictions which we suppress in everyday life in order to get on with it. We suppress what we don't know, what we can't say-you know, Jorie Graham's notorious blanks that everybody's trying to figure out. That has to be brought forward with what you do know, with what you witness, with the kinds of knowledge that aren't public knowledge. It would be something to write a great poem about the CIA training the Savak, the Shah's secret police, who tortured the Ayatollah Khomeni's son to death. Why hasn't any American written that poem?

Clearly, to write a political poetry is complicated. Neruda, in writing "The Heights of Macchu Picchu," wanted to write a poem that was mainly on the side of the working class, but was also about the Spanish destruction of Indian culture-a culture that had its own slaves and its own oppressed class who built its sacred temples. So there's no cause for sentimental opposition between good Indian and bad Spaniard, or for that matter, between good proletariat and bad ruling class. His very language implicates him, so that there can be no luxury of simply being on the right side. So often when writing about history, the temptation is to look at the thing and say these stupidities and evils repeat themselves endlessly-so what else is new. And then you end up with a shrug of irony and a commitment to singularity in art and intelligence. Or you simplify, strike poses-deeply felt probably, but poses. In order to rise above that, you have to be smart, otherwise you end up writing stupid sentimental poems. By smart, I don't mean IQ smart, I mean reflective-you have to have thought some of this stuff out. But finally, I don't think knowledgeeither kind-gets you there. Then what does get you there? It would seem, from the example of the artists who have done it, that among the things that get you there are fidelity to your craft, stubbornly practicing it against all odds, measuring yourself against great examples, against the noblest stuff of art. I want to write, "Ambition, high ambition, for your art," - that actually does seem to help. Brecht had it, Rilke had it, Neruda had it, Whitman had it, Ginsberg has it.

Q: There's a political vision in the prose poem "The Harbor at Seattle" that seems to combine political and historical knowledge with a sense that knowing doesn't get you anywhere. Praise, for example, had a lot of poems that suggest that you can travel and travel and travel but ultimately 
you'll get to a radiant state, not a final knowing. The two suicides in "The Harbor at Seattle" that are never resolved suggest to me that you have a sense that knowing doesn't save things: it doesn't save a political system, it doesn't save Telegraph Hill, it doesn't save the two suicides in that poem, and it doesn't save the fragile relationships among the four people who were the study group in the beginning of the poem. How can you bring that into play with the rest of what we've talked about?

RH: It does seem like a theme of mine; I had never seen it before. Once, I showed something I wrote to a woman who had been studying Charles Olson and Ezra Pound with Hayden Carruth, and she said, "I kind of like that. I kind of like the male ecstatic knowledge trip," which I thought was very funny. I felt incredibly deflated. I think I overvalue knowing, and I think I overvalue knowing because I think my parents would have done better if they had known more. I think it's completely delusory, but knowledge really was power for me in a certain way, because I thought that everything that was out of control in my childhood could be controlled if I just knew more, somehow. So I've probably just been unlearning an obviously wrong thing my whole life.

Q: You've always acknowledged at least in your writing that the knowledge looks like power, but doesn't wind up being power. There are a couple of places where it seems crystalized, where there's an impulse to join the erotic and the knowledgeable and the political lives. "The Harbor at Seattle" posits the suicides and the eating away of Telegraph Hill. The poem knows all, and loves all-I mean there's all this intimacy for these things - loves the photograph of one of the women who committed suicide, and loves the man who committed suicide. And it knows a lot about them, but ultimately Telegraph Hill winds up being destroyed. It seems like a kind of a tragic formulation of how all of the worlds work: the personal world, the political world, and the world of knowledge.

RH: The question of what does save seems to turn on the question also of where politics leaves off. There's the famous story about the First International Congress of Soviet Writers in Moscow in 1934. After three or four long speeches by writers about the socialist future, someone raised his hand and asked, "Mr. Chairman, I would like to know what would happen in 
the socialist state when a beautiful young person got run over by a trolley car." And everybody burst out laughing. On the last day they got Maxim Gorki out of his death bed and propped him up in front of the podium to say that in the perfect socialist state, beautiful young people wouldn't be run over by trolley cars. But the fact is, they would. So it seems to me that without wanting to, I have a slightly dualistic attitude toward politics and whatever other thing art is involved with-maybe religion is the word for it. A task of poetry is to make an image of the common life and of justice. It can make an image of the best possible life that you could intelligently imagine, reasonably imagine. But that life wouldn't satisfy us, because we would still be outraged by nature: early death, AIDS, late death. . . . Milosz was once asked to give a talk at a demonstration against nuclear power plants, and he said, "Why don't they ever demonstrate against old age? It kills far more people." So he's an unrepentant anti-nature dualist who thinks that it's an affront that our individual consciousnesses, with everything they carry, are to perish. He takes a stance against the casual acceptance of death - but does make an effort to have some humility before natural process. It's nevertheless the case that there are all kinds of awful things that are awful not because anybody's done anything stupid or anything bad to anybody else, they're just awful. And so there's a huge part of the human spirit that's wrestling with that. I'm not saying it's not political, because everything that gets cast in this world automatically has a political aspect. But there are things that are not fundamentally political: the problem of suffering, the problem of evil. . . . So in both cases, whether fundamentally political or not, knowledge comes into place mainly in the sense of knowing what it helps to know and what it doesn't help to know.

RH: We were talking last night about Edmond Jabès, a great contemporary French poet and essayist who was born a French-speaking Jew in Cairo and moved to Paris. He took a certain Talmudic training, with its accompanying interest in symbol systems, and married it to a sense of the complete disintegration of the kind of community of symbols that language represents, which includes some feeling that the Holocaust disintegrated the social contract. So really he anticipated, as Paul Celan didthough he's a few years older than Celan - all the notions of Derrida and Lacan and post-structuralist French thought ten or fifteen years before 
they were even warmed up. And he did it through his writing practice. He had Emily Dickinson's kind of ambition - I don't know how to describe it exactly - he certainly wasn't ambitious to be famous. . . But some of those books are such sustained acts of imagination, it takes a certain will to have produced them, I think, which instances that kind of commitment, or obsession.

RH: It's interesting to talk about what's happening in writing right now and where it's going. It's clear that the writing which I grew up with (along with Jim Galvin and Linda Gregg to some extent-Jorie Graham's formation was somewhat different), the writing of the late fifties and early sixties, was a reaction to the writing of the thirties and forties. That whole series of writers of the Ginsberg/O'Hara generation was writing furiously against the new critical formation that came out of Eliot's prose, and the examples of Auden, Yeats, Ransom, and so on. So there was that explosion of energy. But it does seem that in writers younger than I, there has been, among other things, a reawakening interest in formality. One of the signs of it is the so-called new formalism on the right, and language poetry, which has other kinds of formal propositions, on the left. So in general there's some hunger to start wearing starched shirts and blouses again. There's a phrase that comes to mind. Somebody reported to me that coming out of a reading-I don't know who was reading, if it was Robert Bly or Allen Ginsberg - a young woman with shimmery peach and black hair turned to someone and said, "I'm just not interested in the cliché of intensity." I thought, my God, you know, such withdrawal from what has certainly been one of my touchstones. I don't know exactly what the opposite would be-I mean, there are opposites of intensity, like the telephone book, that some of the new poetry puts me in mind of. Dryness and austerity are not the opposite, by the way. Zbigniew Herbert is an intense writer, and in fact dryness can be a sign of intensity in poetry. But there is something going on, and it's related to the question of where we are in history, where our experience is, and what's been done with personal and psychological experience in poetry since 1955 . How can you do anything new with this material, but how can you not write about it? It used to knock me out that Charles Olson's wife died in an automobile accident and he didn't miss a beat in writing The Maximus Poems - it didn't enter 
them, it just didn't enter them, you know, because it wasn't part of that project. For most who began writing, with very few exceptions, since the early sixties, it would be unthinkable that you wouldn't have to somehow deal with that material in your writing. There's so much to get down, so much to express, inside and outside-all religious questions are up for grabs.

My friend Brenda Hillman just finished this long poem about the death of a teacher, a friend, an older woman, and I heard her read a bit of it the other night. Somebody said afterwards that they were hearing something like a feminist - or, not a feminist, a woman's - rewriting of Tennyson's "In Memoriam." But one of the haunting questions in the poem is, where did she go? I mean, we have a common society, but we don't have a common idea about what happens to the dead. We have no common imagination of it. It's a religious matter, it's a private matter, so you just don't talk about it, because it'll only start arguments. And therefore, about the fundamental mysteries of life, we have no agreement; in fact, we have an agreement not to talk about it. You not only don't know what's going to happen to you when you die, you don't know what the person you're talking to thinks about it. In my case, you don't know what you think yourself. There was a period when it was just in bad taste to talk about it, because you looked like such a naive person. Certain post-Sartre intellectuals talked as if it were not an interesting question-embarrassing poetry of that kind was something the Victorians did. The thing I love about C. K. Williams's elegy for Paul Zweig is its philosophical embarrassment. It just opens that question again, like a Victorian poem, as if it were not embarrassing to admit that you don't know what death means, and you don't know how to think about it. You've read a lot of books of philosophy and considered a lot of different answers and the set of prejudices about it - whether you hate the religion or like the religion that you grew up with - none of which may be relevant. And I really do think this is work no art form does the way poetry does it. Nothing gets as close to the absolute feel of the inner life as it asks these questions, because they're questions that have to be answered in words.

With thanks to Eileen Bartos and Carolyn Jacobson for transcribing and editing this talk. 